\title{
APLIKASI GUM ARAB DAN DEKSTRIN SEBAGAI BAHAN PENGIKAT PROTEIN EKSTRAK KEPALA UDANG
}

\section{Application of Arabic Gum and Dextrin as Binder Protein of Shrimp Head Extract}

\author{
Arif Rahman Hakim ${ }^{1^{*}}$ dan Anies Chamidah ${ }^{2}$ \\ ${ }^{1}$ Loka Penelitian dan Pengembangan Mekanisasi Pengolahan Hasil Perikanan, KKP. \\ JI. Imogiri Barat KM 11.5 Jetis, Bantul, DI Yogyakarta 55781. \\ 2 Jurusan Teknologi Hasil Perikanan Universitas Brawijaya. \\ * Korespondensi Penulis: arifrahmanh11@gmail.com
}

Diterima: 9 September 2012, Disetujui: 17 Juni 2013

\begin{abstract}
ABSTRAK
Telah dilakukan penelitian aplikasi gum arab dan dekstrin sebagai pengikat protein terlarut dari ekstrak kepala udang. Tujuan penelitian ini adalah untuk mendapatkan proporsi terbaik dari penambahan gum arab dan dekstrin pada pembuatan bubuk protein sebagai bahan suplementasi nutrisi. Gum arab dan dekstrin yang ditambahkan ialah sebanyak $8 \%(b / v)$, dengan empat perlakuan proporsi yang berbeda yaitu $1: 0,5 ; 1: 1,75 ; 1: 3$; dan $1: 4,25$. Parameter yang diamati untuk mengetahui sifat fisika dan kimia hasil ekstraksi meliputi kadar nitrogen terlarut, kadar nitrogen amino, kadar nitrogen non protein, kadar protein kasar, kadar air, kelarutan, dan rendemen. Hasil penelitian menunjukkan bahwa perlakuan terbaik adalah penambahan gum arab dan dekstrin dengan perbandingan 1:0,5. Produk memiliki kadar nitrogen terlarut 0,55\%, kadar nitrogen amino $2,35 \%$, kadar nitrogen non protein 2,62\%, kadar protein kasar 33,20\%, kadar air 5,67\%, kelarutan $99,15 \%$ dan rendemen $5,04 \%$. Produk ini memenuhi kebutuhan jenis asam amino yang disyaratkan ada pada pangan anak usia 10-14 tahun yang di tetapkan oleh FAO. Produk ini juga memiliki sifat kelarutan yang bagus sebagai bubuk karena kelarutannya diatas 95\%.
\end{abstract}

KATAKUNCI: kepala udang, gum arab, dekstrin, protein terlarut

\section{ABSTRACT}

Study on the application of arabic gum and dextrin to bind soluble protein of shrimp head extract has been conducted. The objective of this research was to find the best proportion of arabic gum and dextrin addition to produce protein powder intended for nutritional supplementation. The addition of arabic gum and dextrin was $8 \%(w / v)$, with four treatments, i.e 1:0.5; 1:1.75; 1:3 and 1:4.25 ratio of arabic gum and dextrin. Parameters observed to determine physical and chemical properties of the extract product were dissolved nitrogen, amino nitrogen, non protein nitrogen, crude protein, moisture content, solubility and yield. Result showed that the best treatment was addition of arabic gum and dextrin with ratio 1:0.5. The product had dissolved nitrogen of $0.55 \%$, amino nitrogen of $2.35 \%$, non protein nitrogen of $2.62 \%$, crude protein of $33.20 \%$, moisture content of $5.67 \%$, solubility $99.15 \%$ and yield $5.04 \%$. This product qualitatively meets FAO requirement for amino acid needed by children age 10-14 years and also had a good performance as powder indicated by the solubility properties of more than $95 \%$.

KEYWORDS: $\quad$ shrimp head, arabic gum, dextrin, dissolved protein

\section{PENDAHULUAN}

Udang merupakan komoditas perikanan yang diandalkan pemerintah untuk menghasilkan devisa negara. Ekspor udang pada tahun 2011 mencapai 153.000 ton (Anon., 2012). Hampir 90\% udang tersebut diekspor dalam bentuk beku, tanpa kulit dan kepala. Oleh karena itu jumlah hasil samping (bagian yang terbuang) dari industri pembekuan udang tersebut cukup besar. Menurut llyas (1993) dan Ferrer et al. (1996) hasil samping dari pengolahan udang beku berupa kepala udang yang tidak digunakan mencapai 30-40\%. Beberapa jenis pemanfaatan kepala udang yang biasa dilakukan antara lain sebagai pakan ternak (Putro, 1986), petis, silase (Ariyani \& Buckle, 1990) dan terasi (Buddyatni et al., 1982) namun cara-cara tersebut belum bisa meningkatkan nilai ekonomisnya (Saleh et al., 1996). 
Kepala udang kaya akan protein yang dapat digunakan sebagai bahan fortifikan pada makanan dan minuman (Giyatmi, 2001; Bueno-Solano et al., 2009). Hal ini dikarenakan protein tersebut tersusun dari asam-asam amino esensial, diantaranya adalah lisin, leusin, isoleusin, treonin, metionin, valin, fenilalanin dan triptofan (Wenhong et al., 2009; El Beltagya et al., 2012). Protein mempunyai peran penting dalam tubuh manusia antara lain untuk menjaga kekebalan tubuh, membantu dalam proses penyembuhan luka, regenerasi sel hingga mengatur kerja hormon dan enzim dalam tubuh (Milne, 2006).

Hingga saat ini pemanfaatan kepala udang sebagai sumber protein untuk pangan sebagian besar dilakukan dengan proses hidrolisis secara enzimatis (Ariyani et al, 2003, Ruttanapornvareesaku et al., 2006, Bueno et al., 2009; Cao et al., 2009), namun cara tersebut memerlukan biaya yang cukup besar dan ketelitian yang tinggi. Pemanfaatan kepala udang sebagai sumber protein tanpa proses enzimatis dapat dilakukan dengan proses asam basa (Chaijan et al, 2010), metode isoelektrik (Gehring et al, 2011), maupun dengan metode mekanis (Binsan et al., 2008)

Ekstraksi protein dari kepala udang dengan metode mekanis dapat dimodifikasi dengan tujuan mendapatkan jenis-jenis protein yang larut dalam air atau sering disebut protein polar yang mengandung jenis-jenis asam amino yang bersifat polar seperti lisin.

Ekstrak kepala udang dalam bentuk bubuk untuk suplementasi protein memiliki beberapa kelebihan dibandingkan dalam bentuk cair, yaitu lebih mudah disimpan dan tidak mudah terkontaminasi dikarenakan kadar air yang rendah (Hartomo \& Widiatmoko, 1993). Bubuk ekstrak kepala udang juga mempunyai daya larut yang tinggi sehingga mudah ditambahkan ke dalam makanan atau minuman yang akan disuplementasi.

Dalam pembuatan bubuk dari suatu cairan dibutuhkan bahan pengisi yang berfungsi juga sebagai bahan pengikat yang disebut binding agent atau binder. Menurut Abdelgader et al. (2011) dan Sarkar et al. (2012), gum arab dapat diaplikasikan sebagai binding agent bahan pangan maupun bahan obat. Selain itu gum arab bersifat sebagai emulsifier sehingga bahan yang telah diproses dengan penambahan gum arab akan mudah dilarutkan dalam air maupun minyak. Sementara itu dekstrin dapat digunakan sebagai bahan enkapsulasi senyawa volatile dan minyak (Aghbashlo et al., 2012), sehingga dapat melindungi senyawa yang peka terhadap oksidasi atau panas. Karena molekul dekstrin stabil terhadap panas dan oksidasi (Abadio et al., 2004).

Penggunaan gum arab dan dekstrin pada ekstrak kepala udang diharapkan mampu menjadi bahan pengikat protein yang baik dan melindunginya dari proses panas saat pengeringan maupun proses berikutnya.

Tujuan dari penelitian ini adalah untuk mengetahui proporsi terbaik gum arab dan dekstrin sebagai bahan pengikat protein terlarut ekstrak kepala udang, yang nantinya bisa digunakan sebagai bahan dasar suplementasi protein.

\section{BAHAN DAN METODE}

\section{Bahan}

Bahan baku yang digunakan dalam penelitian ini adalah kepala udang Vannamei (Litopenaeus vannamei) yang diperoleh dari hasil samping proses pembekuan udang PT. Bumi Menara Internusa di Dampit Kabupaten Malang. Kepala udang tersebut dibawa ke Laboratorium Biokimia dan Teknologi Hasil Perikanan Universitas Brawijaya Malang dalam kondisi dingin (suhu $4-6^{\circ} \mathrm{C}$ ). Bahan pengikat berupa gum arab dan dekstrin diperoleh dari Toko Kimia Panadia Malang. Peralatan yang digunakan dalam penelitian ini adalah timbangan, waterbath, kain saring, homogenizer ultra urrax T50, spray dryer MerkArmfield SD-04, sentrifuge, dan amino acid analyzer.

\section{Penelitian Tahap I}

Penelitian tahap pertama bertujuan untuk menentukan proses ekstraksi yang dapat menghasilkan rendemen protein terlarut terbanyak yang akan digunakan pada penelitian tahap II. Rancangan percobaan dilakukan dengan 2 perlakuan yaitu tanpa pemanasan dan dengan pemanasan.

Prosedur penelitian tahap I adalah sebagai berikut: Kepala udang dicuci, dibersihkan dan dibuang cangkangnya, kemudian ditambahkan aquades sebanyak 2 kali berat bahan baku, lalu dihancurkan dengan menggunakan blender. Hancuran kepala udang dibagi menjadi 2 bagian, sebagian tanpa dipanaskan (perlakuan A) sebagian lagi dipanaskan pada suhu $70^{\circ} \mathrm{C}$ selama 30 menit (perlakuan B). Masing-masing bagian disaring dengan kain saring. Filtrat yang diperoleh masing-masing disentrifuse pada suhu kamar dengan kecepatan 3500 rpm selama 30 menit. Filtrat hasil sentrifuse diamati profil dan konsentrasi asam aminonya. Perlakuan yang menghasilkan asam amino lebih tinggi digunakan pada penelitian berikutnya.

\section{Penelitian Tahap II}

Penelitian tahap kedua dilakukan untuk menentukan pengaruh jenis bahan pengikat (dekstrin dan gum arab) terhadap pengikatan protein terlarut 
untuk menghasilkan produk bubuk protein. Penelitian diulang sebanyak 3 kali. Metode ekstraksi menggunakan metode Binsan et al. (2008),yang telah dimodifikasi, yaitu dengan pemanasan hingga suhu $70^{\circ} \mathrm{C}$ selama 30 menit sebelum dilakukan penyaringan.

Dari hasil penelitian sebelumnya, konsentrasi gum arab dan dekstrin sebanyak 8\% menghasilkan kestabilan yang paling baik dan paling cepat larut. Nilai tersebut selanjutnya digunakan untuk penelitian tahap II. Perbandingan jumlah gum arab dan desktrin yang ditambahkan sebagai bahan pengikat adalah sebagai berikut:

1. B1: gum arab $(5,33 \%)$ : dekstrin $(2,67 \%)=1: 0,5$

2. B2: gum arab $(2,91 \%)$ : dekstrin $(5,09 \%)=1: 1,75$
3. B3: gum arab $(2,00 \%)$ : dekstrin $(6,00 \%)=1: 3$

4. B4: gum arab $(1,52 \%)$ : dekstrin $(6,46 \%)=1: 4,25$ Proses pembuatan bubuk protein terlarut (Gambar 1) meliputi: sortasi, pembuangan cangkang, pencucian, penambahan aquades, penghancuran bahan baku, pemanasan, filtrasi, sentrifugasi, pemisahan supernatan dan residu, penambahan bahan pengikat, homogenasi larutan, pengeringan dengan spray dryer.

\section{Parameter yang Diamati}

Parameter uji yang diamati meliputi nitrogen total atau protein kasar dengan metode Kjeldahl (AOAC, 1990), kadar nitrogen terlarut, kadar nitrogen amino, kadar nitrogen non protein, kelarutan (Sudarmadji et

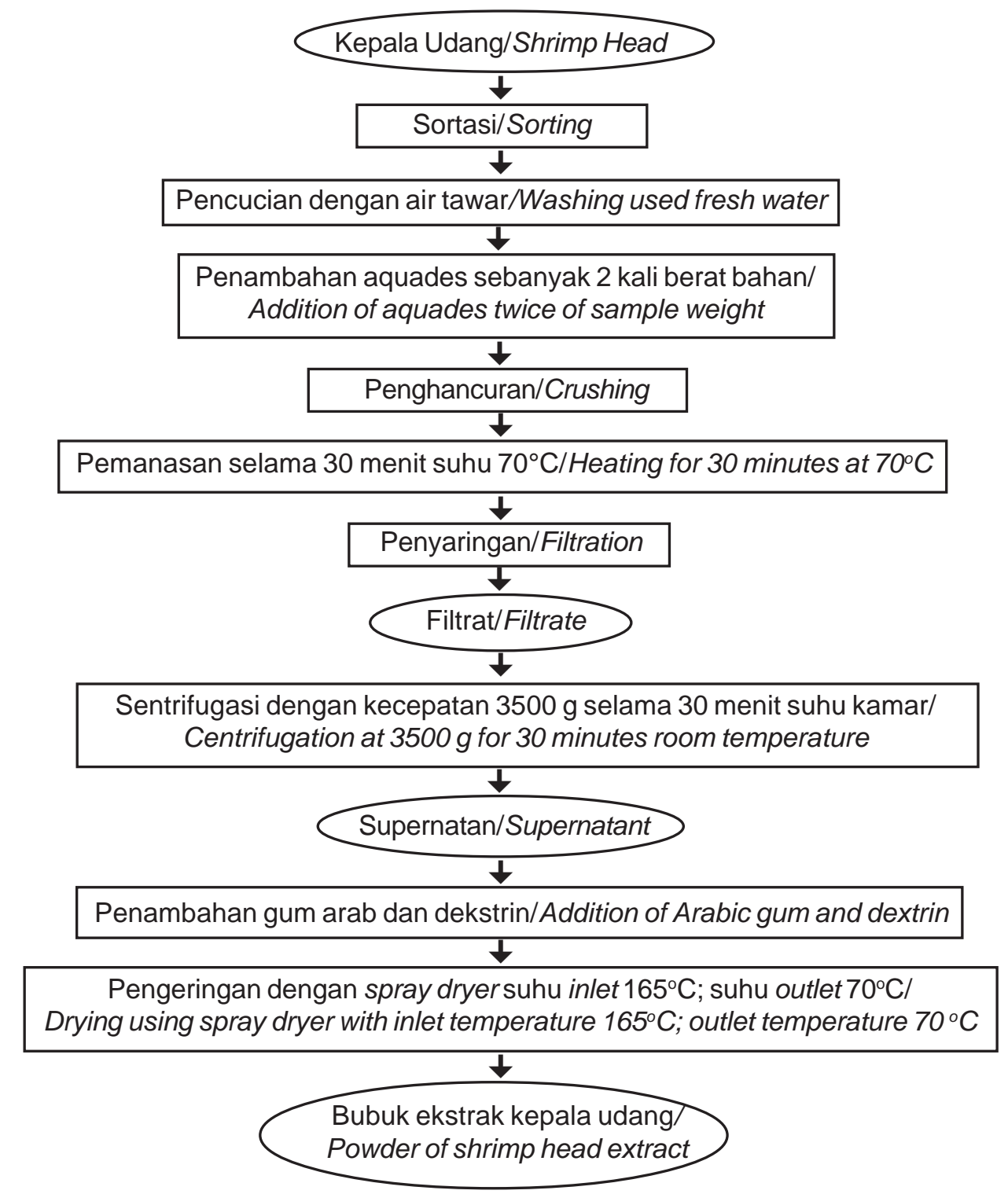

Gambar 1. Proses pembuatan bubuk ekstrak kepala udang.

Figure 1. Production of shrimp head extracts powder. 
al., 1997), kadar air dengan metode thermogravimetri (Sudarmadji et al. , 1997), profil asam amino dengan Amino Acid Analyzer Model 835 dan rendemen.

\section{HASIL DAN BAHASAN}

\section{Penelitian Tahap I}

Penelitian tahap pertama dilakukan untuk mengetahui perbandingan antara perlakuan pemanasan pada suhu $70^{\circ} \mathrm{C}$ dengan perlakuan tanpa pemanasan pada proses ekstraksi protein dari kepala udang. Dari hasil analisis profil asam amino, diperoleh 15 jenis asam amino dari bubuk ekstrak kepala udang untuk masing-masing perlakuan. Tiga jenis asam amino tidak terdeteksi, yaitu metionin, sistein dan triptopan. Hal ini diduga karena kondisi proses deteksi melalui hidrolisis asam selama 24 jam pada suhu $110^{\circ} \mathrm{C}$, menyebabkan hampir semua sistein dan triptofan rusak demikian pula metionin (Bunka et al., 2009). Profil asam amino yang diperoleh dapat dilihat pada Tabel 1.

Perlakuan dengan pemanasan menghasilkan jumlah asam amino yang lebih tinggi dibandingkan dengan perlakuan tanpa pemanasan. Hal tersebut dikarenakan pada saat ekstraksi menggunakan suhu $70^{\circ} \mathrm{C}$, protein yang terlepas dari dinding sel semakin banyak. Menurut Silvia et al. (2012), penggunaan suhu yang semakin tinggi (sampai batas tertentu) akan meningkatkan kekuatan ekstraksi. Hal tersebut dikarenakan suhu yang semakin tinggi menyebabkan dinding sel jaringan lebih mudah rusak, sehingga protein lebih mudah larut dalam larutan pengekstrak. Tabel 1 menunjukkan bahwa jenis asam amino antara perlakuan tanpa pemanasan dan dengan pemanasan tidak berbeda. Perlakuan pemanasan tidak mengakibatkan putusnya ikatan peptida dan sulfida antar asam amino sehingga jenis asam amino tidak berubah. Menurut Bunka et al. (2009), untuk memutuskan ikatan-ikatan yang kuat (peptide dan disulfide) antar asam amino tanpa bantuan asam, basa atau enzim dibutuhkan suhu $200^{\circ} \mathrm{C}$.

Berdasarkan hasil dari tahap I dapat disimpulkan bahwa ekstraksi dengan pemanasan menghasilkan asam amino lebih tinggi dibandingkan dengan tanpa pemanasan, sehingga pada penelitian tahap II atau penelitian inti proses ekstraksi dilakukan dengan pemanasan pada suhu $70^{\circ} \mathrm{C}$ selama 30 menit.

\section{Penelitian Tahap II}

Hasil penelitian tahap II memperlihatkan bahwa perlakuan penambahan gum arab dan dekstrin berpengaruh secara signifikan $(p<0,05)$ terhadap nitrogen terlarut (N-terlarut), nitrogen amino (N-Amino), nitrogen non protein (NPN) dan total protein kasar produk.

Tabel 1. Hasil analisis profil dan kadar asam amino (g/100g ekstrak)

Table 1. Result analysis of amino acids profil and content ( $\mathrm{g} / 100 \mathrm{~g}$ extract)

\begin{tabular}{clcc}
\hline No. & \multicolumn{1}{c}{$\begin{array}{c}\text { Jenis Asam Aminol } \\
\text { Amino Acids Type }\end{array}$} & $\begin{array}{c}\text { Tanpa Pemanasan/ } \\
\text { Without Heating }\end{array}$ & $\begin{array}{c}\text { Dengan Pemanasan/ } \\
\text { With Heating }\end{array}$ \\
\hline 1 & Aspartat/aspartic & 1.66 & 1.97 \\
2 & Treonin/Threonine & 0.71 & 0.80 \\
3 & Serin/Serine & 0.58 & 0.86 \\
4 & Glutamat/Glutamic & 2.25 & 3.71 \\
5 & Glisin/Glycine & 1.15 & 1.49 \\
6 & Alanin/alanine & 1.54 & 1.72 \\
7 & Sistein/Cystine & - & - \\
8 & Valin/Valine & 0.80 & 0.87 \\
9 & Metionin/Methionine & - & - \\
10 & Isoleusin/Isoleucine & 0.75 & 0.78 \\
11 & Leusin/Leucine & 1.16 & 1.36 \\
12 & Tirosin/Tyrosine & 0.21 & 0.40 \\
13 & Fenilalanin/Phenylalanine & 0.66 & 0.58 \\
14 & Lisin/Lysine & 1.14 & 1.40 \\
15 & Histidin/Histidine & 0.38 & 0.38 \\
16 & Arginin/Arginine & 1.03 & 1.56 \\
17 & Prolin/Proline & 0.91 & 1.16 \\
\hline & Jumlah & 15.22 & 19.06 \\
\hline
\end{tabular}




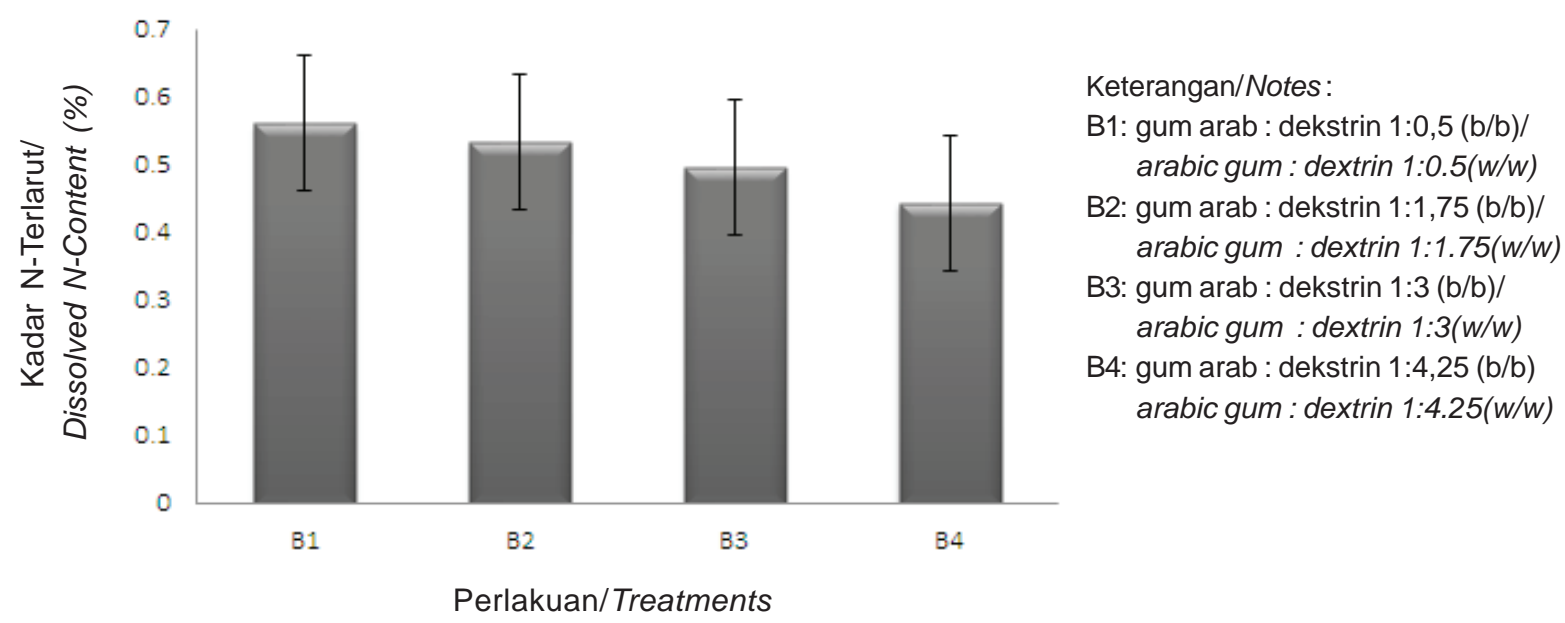

Gambar 2. Kadar nitrogen terlarut bubuk ekstrak kepala udang.

Figure 2. Dissolved nitrogen of shrimp head extract powder.

Kadar N-terlarut tertinggi adalah 0,55\% pada perlakuan B1 yaitu penambahan gum arab : dekstrin $(1: 0,5)$ dan terendah pada perlakuan B4 yaitu penambahan gum arab : dekstrin $(1: 4,25)$ sebesar $0,45 \%$ (Gambar 2).

Nitrogen terlarut adalah hasil pemecahan protein menjadi bentuk sederhana seperti peptida dan oligopeptida hingga terbentuk asam-asam amino bebas yang terlarut dalam air, sedangkan protein terlarut adalah konsentrasi nitrogen protein yang larut dalam air dan tidak mengendap bila dikenai gaya sentrifugal sedang yaitu 3000-5000 g (Binsan et al., 2008).

Kadar nitrogen amino adalah nitrogen dalam bahan yang dianggap sebagai asam amino bebas. Kadar nitrogen amino tertinggi pada penelitian ini ialah 2,35\% yang diperoleh dari perlakuan penambahan gum arab : dekstrin $(1: 0,5)$, dan terendah pada perlakuan penambahan gum arab : dekstrin $(1: 4,25)$ yaitu $1,52 \%$ (Gambar 3).

Kadar protein tertinggi diperoleh pada perlakuan penambahan gum arab:dekstrin $(1: 0,5)$ sebesar $33,20 \%$, sedangkan kadar protein terendah yaitu $27,42 \%$ pada perlakuan penambahan gum arab : dekstrin $(1: 4,25)$ (Gambar 4).

Ketiga parameter tersebut menunjukkan bahwa dengan semakin tingginya penambahan konsentrasi gum arab dan semakin sedikitnya konsentrasi dekstrin, menyebabkan kandungan nitrogen dalam produk ini semakin tinggi. Hal ini disebabkan oleh komposisi yang berbeda antara gum arab dan dekstrin. Gum arab terdiri dari arabinogalactan (AG),

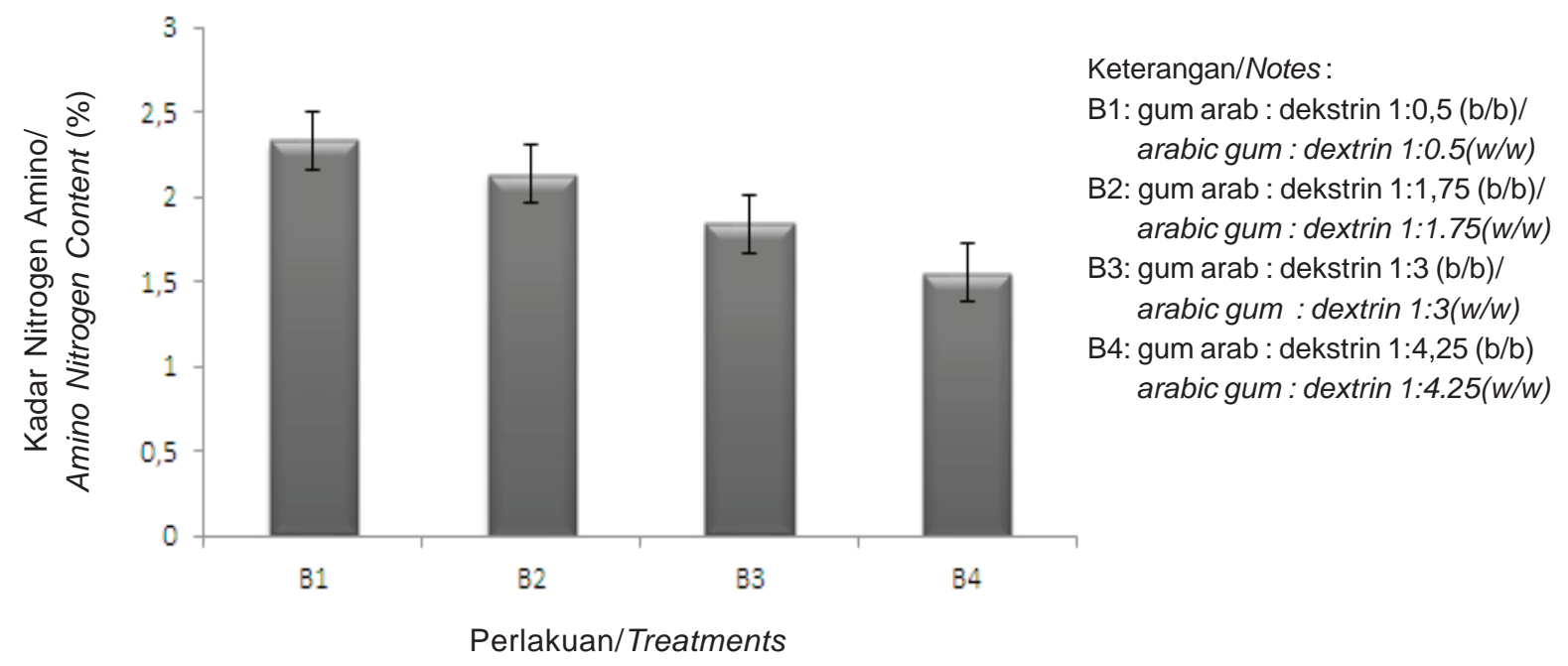

Gambar 3. Kadar nitrogen amino bubuk ekstrak kepala udang. Figure 3. Amino Nitrogen content of shrimp head extract powder. 


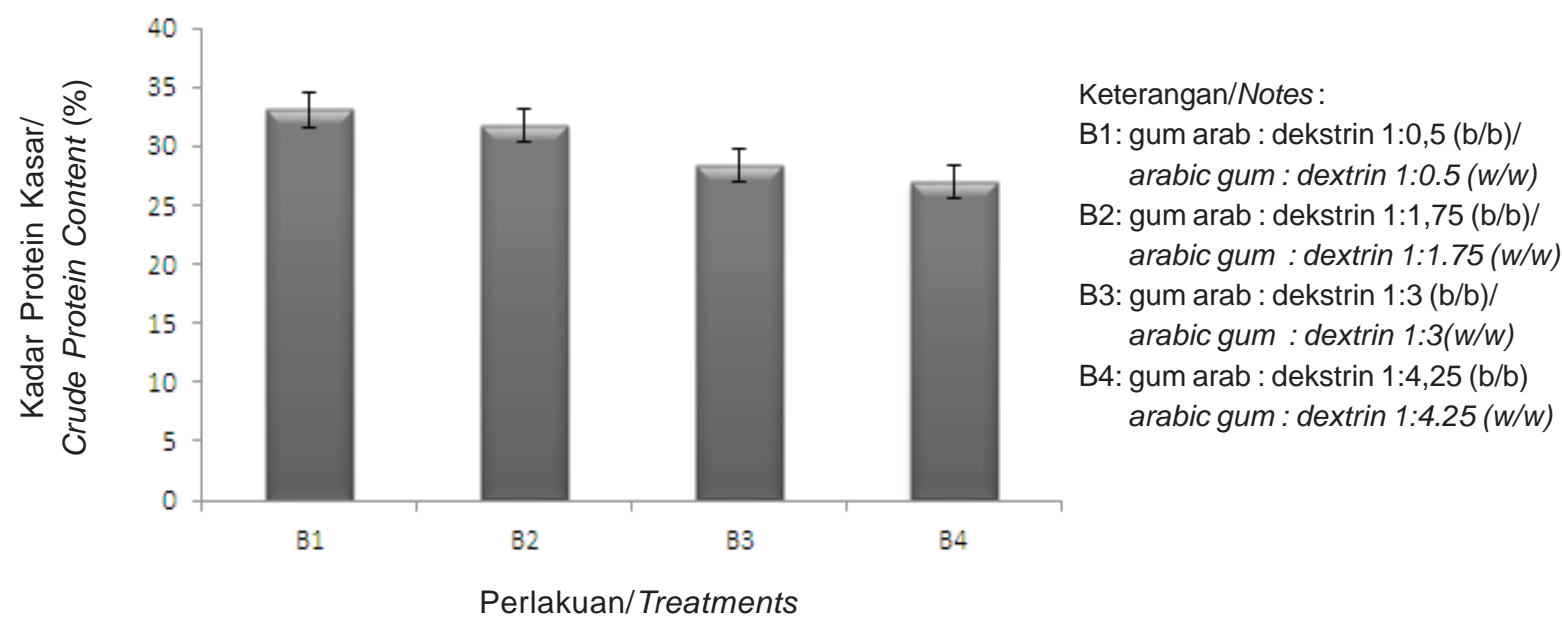

Gambar 4. Kadar protein kasar bubuk ekstrak kepala udang.

Figure 4. Crude Protein Content of shrimp head extract powder.

arabinogalactan protein (AGP) dan glycoprotein (GP) (Gaonkar, 1995). AGP dan GP inilah yang berperan dalam penambahan nitrogen di dalam produk ini baik berupa nitrogen terlarut, nitrogen amino dan total protein. Diduga protein dalam gum arab ini juga berkontribusi dalam pengikatan ekstrak melalui ikatan nonkovalen antar polipeptida sehingga makin banyak nitrogen yang terikat pada AGP dan GP.

Menurut Mahendran et al. (2008), larutan gum arab sering dipakai sebagai emulsifier, karena adanya protein yang terikat pada rantai polisakarida. Penambahan dekstrin yang semakin meningkat tidak menunjukkan peningkatan terhadap pengikatan protein. Hal ini karena dekstrin merupakan polisakarida yang tidak mengandung protein sehingga mempengaruhi kemampuan pengikatan protein terlarut. Menurut Martinez et al. (2007) interaksi antara protein dan polisakarida dalam larutan akan terbentuk melalui ikatan elektrostatik dimana pada $\mathrm{pH}$ biologis gugus protein akan bertindak sebagai polikation dan gugus karboksil polisakarida bertindak sebagai polianion.

Nitrogen non protein (NPN) merupakan nitrogen dalam suatu bahan yang tidak membentuk protein, terdiri dari asam-asam amino bebas, senyawa volatil nitrogen (TMAO), serta kreatin (Carratu et al., 2003). Pada Gambar 5, dapat dilihat bahwa kadar rata-rata NPN berkisar antara 2,19-2,64\%.

Kadar NPN menurun dengan menurunnya jumlah gum arab yang ditambahkan. Gum arab akan lebih mudah mengikat senyawa NPN dibandingkan dengan dekstrin. Karena gum arab mempunyai gugusan protein yang mempermudah pengikatan senyawa NPN tersebut (Yebeyen et al, 2009)

Rata-rata kadar air produk yang dihasilkan berkisar antara 5,16-9,51\% Berdasarkan hasil analisis uji

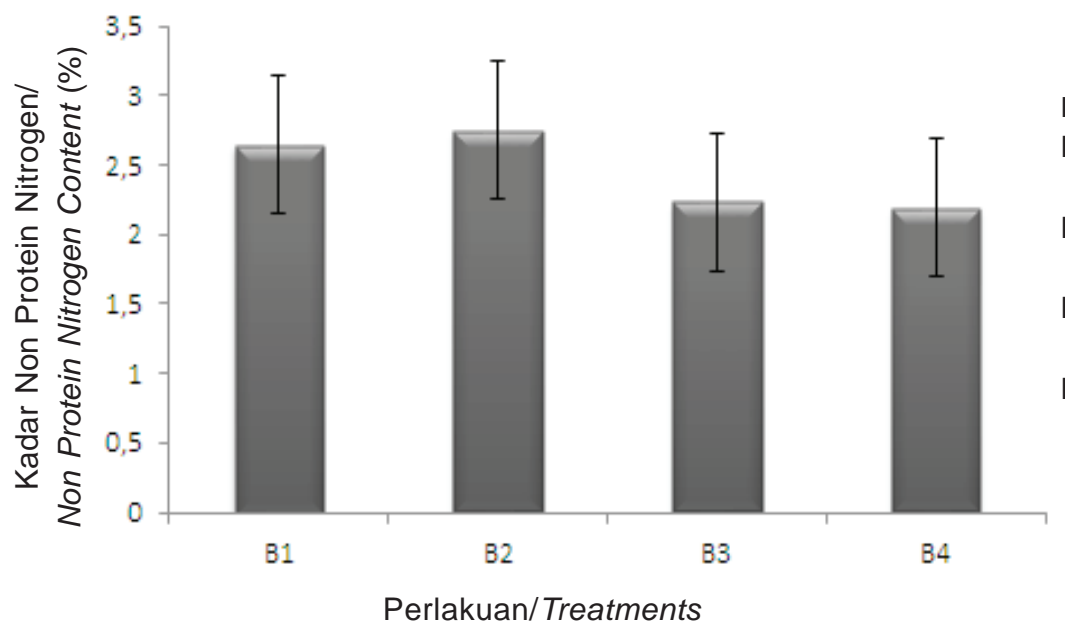

Keterangan/Notes :

B1: gum arab : dekstrin 1:0,5 (b/b)/ arabic gum : dextrin 1:0.5 (W/W)

B2: gum arab : dekstrin 1:1,75 (b/b)/ arabic gum : dextrin 1:1.75 (w/W)

B3: gum arab : dekstrin 1:3 (b/b)/ arabic gum : dextrin 1:3(w/W)

B4: gum arab : dekstrin 1:4,25 (b/b) arabic gum : dextrin 1:4.25 (w/W)

Gambar 5. Kadar non protein nitrogen bubuk ekstrak kepala udang. Figure 5.. Non Nitrogen Protein content of shrimp head extract powder. 
lanjut dapat diketahui bahwa kadar air terendah diperoleh pada perlakuan B1 yang tidak berbeda nyata dengan perlakuan B2, sedangkan kadar air tertinggi diperoleh pada perlakuan B3 yang tidak berbeda nyata dengan perlakuan B4 (Gambar 6).

Kadar air produk cenderung meningkat dengan meningkatnya konsentrasi dekstrin yang ditambahkan. Hal ini diduga karena pengaruh dari jenis bahan pengikat yang ditambahkan pada perlakuan. Nugroho et al. (2006) menyebutkan bahwa perbedaan kadar air bahan disebabkan karena kemampuan bahan-bahan pengikat tersebut dalam mengikat air berbeda-beda. Dekstrin mempunyai kemampuan lebih kuat dalam mengikat air. Hal tersebut disebabkan karena dekstrin merupakan golongan polisakarida yang mempunyai struktur kimia yang lebih sederhana terdiri dari ikatan-ikatan 1,6 $\alpha$-glukosidik dan 1,4 $\alpha$ glukosidik (Xu et al., 2012). Dextrin juga lebih mudah menyerap air dibanding dengan gum arab yang memiliki struktur kimia lebih komplek, yaitu terdiri dari D-galaktosa, L-arabinosa, asam D-glukuronat, dan Lrhamnosa (Alftren et al., 2012).

Kelarutan merupakan parameter penting pada produk bubuk ekstrak kepala udang, yang akan menentukan kemudahan aplikasi produk tersebut. Rata-rata kelarutan produk bubuk ekstrak protein berkisar antara 98,67-99,40\% (Gambar 7). Hasil uji sidik ragam tidak menunjukkan perbedaan nyata antar

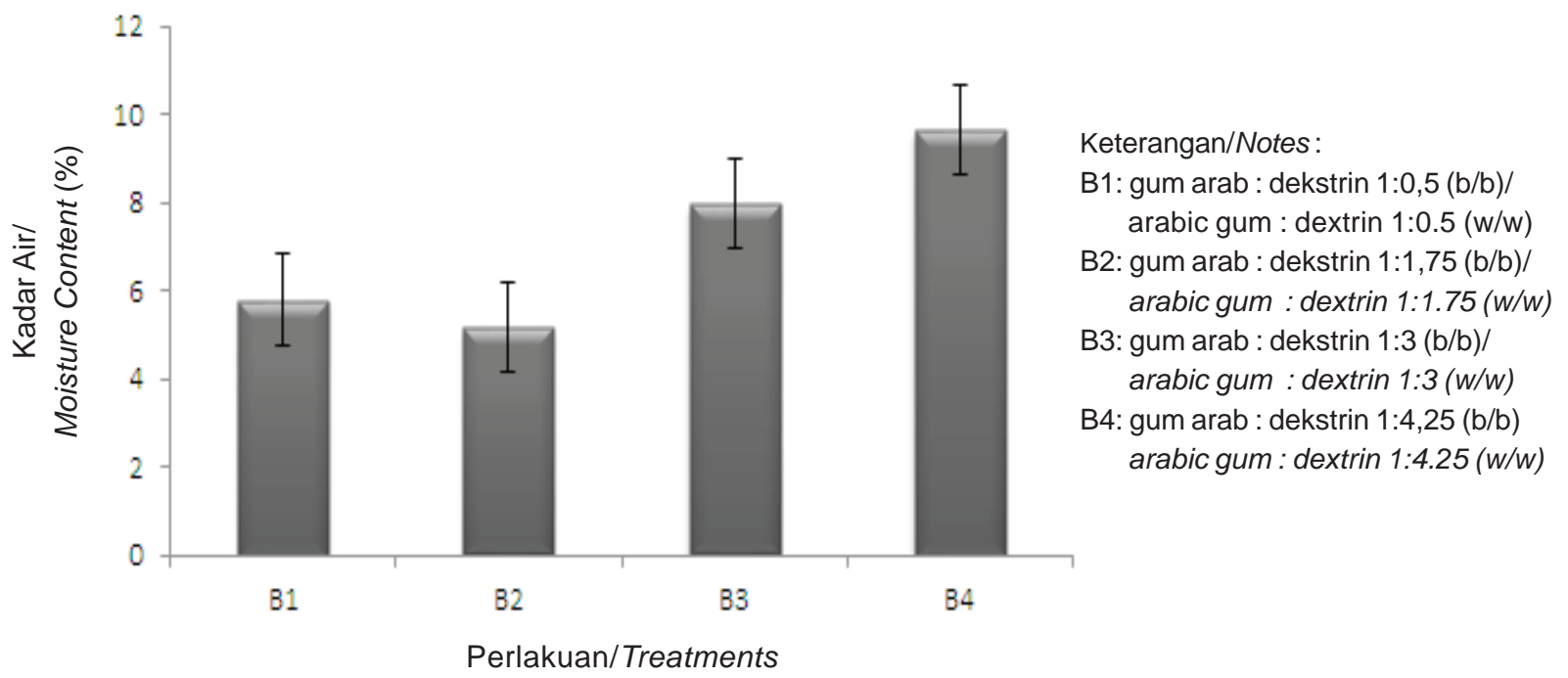

Gambar 6. Kadar air bubuk ekstrak kepala udang.

Figure 6. Moisture content of shrimp head extract powder.

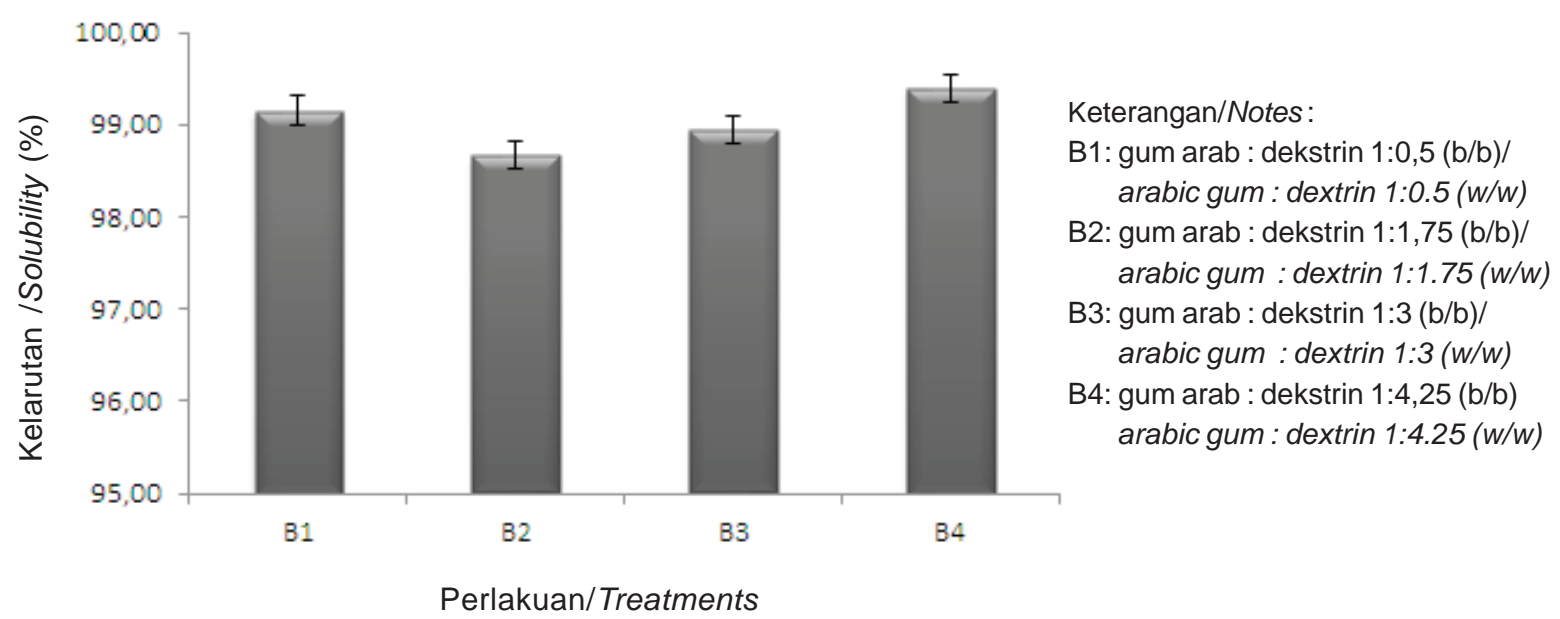

Gambar 7. Rata-rata kelarutan bubuk ekstrak kepala udang.

Figure 7. Mean of solubility of shrimp head extract powder. 


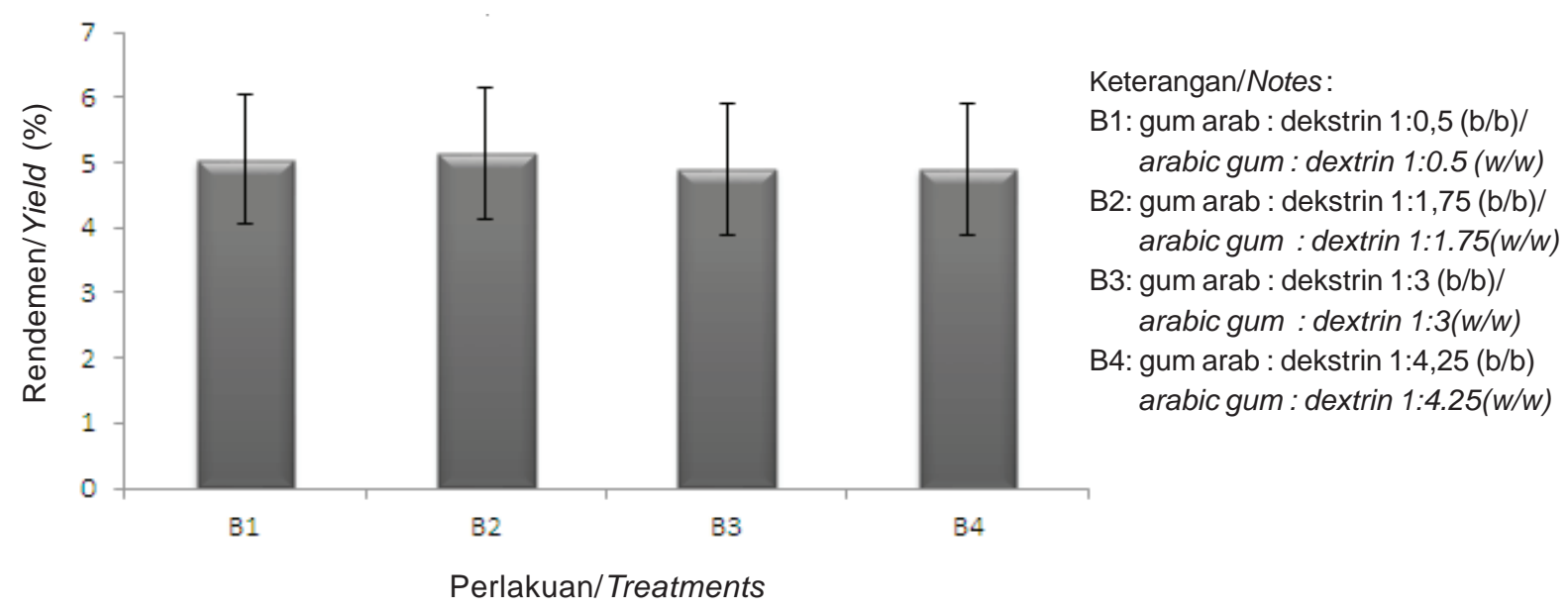

Gambar 8. Rata-rata rendemen bubuk ekstrak kepala udang.

Figure 8. Mean of Yield of shrimp head extract powder.

perlakuan $(p>0,05)$. Kelarutan bubuk dipengaruhi oleh jenis dan konsentrasi bahan pengisi atau pengikat yang digunakan saat dilakukan proses pengeringan. Hal ini disebabkan konsentrasi total bahan pengisi untuk setiap perlakuan sama besar yaitu $8 \%$. Sedangkan jenis bahan pengisi gum arab dan dekstrin sama-sama mempunyai daya kelarutan yang tinggi dalam air.

Rendemen pada penelitian ini (Gambar 8) adalah rendemen yang dihasilkan dalam proses pengeringan. Nilai rendemen diperoleh dari perbandingan volume supernatan yang telah ditambahkan bahan pengikat

Tabel 2. Perbandingan jumlah asam amino berbagai produk

Table 2. Ratio of amino acids content in various products

\begin{tabular}{|c|c|c|c|c|c|}
\hline No & $\begin{array}{l}\text { Jenis Asam Aminol } \\
\text { Amino Acids Type }\end{array}$ & $\begin{array}{l}\text { Ekstrak Protein } \\
\text { Kepala Udangl } \\
\text { Protein Shrimp } \\
\text { Head Extract } \\
(\mathrm{g} / 100 \mathrm{~g})\end{array}$ & $\begin{array}{c}\text { Hidrolisat } \\
\text { Protein Ikan/ } \\
\text { Fish Protein } \\
\text { Hydrolisate } \\
\text { (g/100 g) } \\
\text { (Nilsang et al. , } \\
2005 \text { ) }\end{array}$ & $\begin{array}{c}\text { Hidrolisat } \\
\text { Protein Ikan/ } \\
\text { Fish Protein } \\
\text { Hydrolisate } \\
\text { (g/100 g ) } \\
\text { (Ovissipour et } \\
\text { al. , 2009) }\end{array}$ & $\begin{array}{c}\text { Kebutuhan Minimal } \\
\text { Protein Anak Usia 10-14 } \\
\text { Tahun/Minimum Daily } \\
\text { Protein Intake for } \\
\text { Children 10-14 years old } \\
\text { (mg/kg/hari) } \\
\text { (FAO, 2011) }\end{array}$ \\
\hline 1 & Aspartat/aspartic & 1.97 & 0.67 & 8.3 & - \\
\hline 2 & Treonin/ Threonine & 0.80 & 0.74 & 3.5 & 18 \\
\hline 3 & Serin/Serine & 0.86 & 0.67 & 4.2 & - \\
\hline 4 & Glutamat/Glutamic & 3.71 & 1.52 & 13.7 & - \\
\hline 5 & Glisin/Glycine & 1.49 & 2.98 & 5.4 & - \\
\hline 6 & Alanin/Alanine & 1.72 & 1.33 & 6.3 & - \\
\hline 7 & Sistein/Cystine & - & - & - & - \\
\hline 8 & Valin/valine & 0.87 & 0.56 & 5.79 & 29 \\
\hline 9 & Metionin/ Methionine & - & 0.48 & 10.3 & - \\
\hline 10 & Isoleusin/Isoleucine & 0.78 & 0.35 & 3.8 & 22 \\
\hline 11 & Leusin/ Leucine & 1.36 & 0.77 & 7.13 & 44 \\
\hline 12 & Tirosin/ Tyrosine & 0.40 & 0.40 & 2.34 & - \\
\hline 13 & Fenilalanin/ & 0.58 & 0.64 & 3.14 & - \\
\hline 14 & Lisin/ Lysine & 1.40 & 0.54 & 6.80 & 35 \\
\hline 15 & Histidin/ Histidine & 0.38 & 0.206 & 2.08 & 12 \\
\hline 16 & Arginin/Arginine & 1.56 & 2.70 & 7.28 & - \\
\hline 17 & Prolin/ Proline & 1.16 & 1.45 & 3.46 & - \\
\hline 18 & Sulfur amino acids & - & - & - & 17 \\
\hline 19 & Aromatic amino acids & - & - & - & 30 \\
\hline
\end{tabular}


sebelum dikeringkan dengan berat bubuk yang dihasilkan setelah pengeringan menggunakan spray dryer. Analisis sidik ragam rendemen menunjukkan bahwa perlakuan penambahan bahan pengikat dengan proporsi gum arab dan dekstrin yang berbeda tidak berpengaruh terhadap rendemen bubuk ekstrak kepala udang.

Ekstrak protein kepala udang memiliki jenis asam amino yang sama seperti yang dimiliki oleh hidrolisat protein ikan hasil penelitian Nilsang et al. (2005) dan Ovissipour et al. (2009). Ekstrak kepala udang yang dihasilkan pada penelitian ini juga mengandung asam amino aromatik yaitu fenilalanin dan tirosin dengan konsentrasi masing-masing 0,58 dan 0,40 g/100 g ekstrak. Namun jika dibandingkan dengan kebutuhan minimal suplementasi protein pada anak usia 10-14 tahun yang disyaratkan oleh FAO, produk ini harus ditambahkan jenis asam amino yang mengandung sulfur (Tabel 2). Asam amino yang mempunyai gugus sulfur terdiri dari sistein dan metionin (Park et al., 2012), namun pada ekstrak kepala udang hasil penelitian ini tidak terdeteksi.

Secara umum bubuk ekstrak protein ini mempunyai potensi untuk dikembangkan menjadi bahan dasar suplementasi protein karena mengandung asam amino essensial di antaranya lisin. Lisin terbukti mampu meningkatkan sistem antivirus dan kekebalan tubuh sehingga lisin banyak di tambahkan pada produk makanan (Virag et al., 2013).

Ekstraksi dengan metode yang digunakan dalam penelitian menghasilkan jenis asam amino yaitu aspartat, treonin, serin, glutamine, glisin, alanin, valin, isoleusin, leusin, tirosin, fenilalanin, lisin, histidin, dan arginin. Jenis yang sama didapatkan dengan proses yang dilakukan Bueno et al. (2009), dalam menghasilkan hidrolisat protein. Namun demikian jumlah nitrogen terlarut, nitrogen amino, dan protein kasar masih lebih rendah bila dibandingkan dengan ekstraksi menggunakan enzim.

\section{KESIMPULAN}

Ekstraksi protein menggunakan pemanasan pada suhu $70^{\circ} \mathrm{C}$ selama 30 menit menghasilkan ekstrak protein dengan jumlah asam amino yang lebih tinggi dibandingkan dengan ekstraksi tanpa pemanasan. Ekstrak protein yang diberi perlakuan penambahan gum arab:dekstrin $(1: 0,5)$ atau perlakuan B1 menghasilkan produk ekstrak protein bubuk dengan kadar nitrogen terlarut $0,55 \%$, kadar nitrogen amino 2,33\%, kadar nitrogen non protein 2,62\%, kadar protein kasar $33,20 \%$, kadar air $5,67 \%$ dan rendemen $5,04 \%$.

\section{UCAPAN TERIMA KASIH}

Ucapan terima kasih disampaikan kepada Dekan Fakultas Perikanan dan Kelautan Universitas Brawijaya atas izinnya melakukan penelitian di Laboratorium Biokimia dan THP, dan juga Dr. Ekowati Chasanah, yang telah memberi banyak masukan pada artikel ini.

\section{DAFTAR PUSTAKA}

Anonim. 2012. Kelautan dan Perikanan dalam Angka 2011. Kementerian Kelautan dan Perikanan, Jakarta.

Abadio, F.D.B., Domingues, A.M., Borges, S.V., and Oliveira, V.M. 2004. Physical properties of powdered pineapple (Ananas comosus) juice effect of malt dextrin concentration and atomization speed. Journal of Food Engineering. 64: 285-287.

Abdelgader, M.O. and Inaam, A.I. 2011. Application of Gum Arabic for coating of dried manggo slices. Journal of Nutrition.10(5): 457-462.

Alftrén, J., Peñarrieta, J.M., Bergenståhl, B., Nilssona, L. 2012. Comparison of molecular and emulsifying properties of gum Arabic and mesquite gum using asymmetrical ûow ûeld-ûow fractionation. Food Hydrocolloids. p. 54-62.

Aghbashlo, M., Mobli, H., Madadlou, A., Rafiee, S. 2012. The correlation of wall material composition with flow characteristics and encapsulation behavior of fish oil emulsion. Food Research International. 49: 379388.

Ariyani, F. dan Buckle, K.A. 1990. Perubahan kimia selama likuifaksi silase kepala udang. Jurnal Penelitian Pasca Panen Perikanan. 63: 37-43.

Ariyani, F., Saleh, M., Tazwir., dan Hak, N. 2003. Optimasi proses produksi hidrolisat protein ikan (HPI) dari mujair (Oreochromis mossambicus). Jurnal Penelitian Perikanan Indonesia. 9(5): 11-21.

Association of Official Analytical Chemist (AOAC), 1990. Official Methods of Analysis. Virginia:15 th ed. Vol. 2

Binsan,W., Benjakul,S., Visessanguan,W., Roytrakul,S., Tanaka, M., and Kishimura, H. 2008. Antioxidative activity of Mungoong, an extract paste, from the cephalothorax of white shrimp (Litopenaeus vannamei).Journal of Food Chemistry. 106: 185-193

Buddyatni, S., Murtini, J.T., dan Peranginangin, R. 1982. Studi Mikroflora pada Terasi Bubuk. Laporan Penelitian Teknologi Perikanan No.16.

Bueno-Solano,C., López-Cervantes, J., Campas-Baypoli, O.N., Lauterio-García, R., Adan-Banteand, N.P., and Sánchez-Machado, D.I. 2009. Chemical and biological characteristics of protein hydrolysates from fermented shrimp by-products. Food Chem. 112: 671-675.

Bunka, F., Krýz, O., Velickova, A., Bunkova, L., and Kracmar, S., 2009. Effect of acid hydrolysis time on amino acid determination in casein and processed cheeses with different fat content. Journal of Food Composition and Analysis. 22: 224-232.

Cao, W., Zhang, C., Hong, P., Ji, H., Hao, J., Zhang, J. 2009. Autolysis of shrimp head by gradual 
temperature and nutritional quality of theresulting hydrolysate. Food Science and Technology. 42: 244249.

Carratu, B., Boniglia,C., Scalise, F., Ambruzzi, A.M., and Sanzinia, E. 2003. Nitrogenous components of human milk: non-protein nitrogen, true protein and free amino acids. Food Chemistry. 81: 357-362.

Chaijan, M., Panpipat, W., and Benjakul, S. 2010. Physicochemical and gelling properties of shortbodies mackerel (Rastrelliger brachysoma) protein isolate prepared using alkaline-aided process. Food and Bioproducts Processing. 88(2-3): 174-180.

El-Beltagya, A.E. and El-Sayed, S.M. 2012. Functional and nutritional characteristics of protein recovered during isolation of chitin from shrimp waste. Journal food and bioproducts processing. 90: 633-638.

Ferrer, J., Paez, G., Marmol, Z., Ramones, E., Garcia, H., and Forster, C.F. 1996. Acid hydrolysis of shrimp-shell wastes and the production of single cell protein from the hydrolysate. Bioresour. Technol. 57: 55-60.

Food and Agricultural Organization (FAO). 2011. Dietary Protein Quality Evaluation In Human Nutrition. Food and Agricultural Organization of the United Nations Report of An FAO Expert Consultation. Rome. FAO.

Gaonkar, A. 1995. Ingredient Interactions: Effects on Food Quality. Vol. 66. Food Science and Technology Ser., English. Dekker Incorporated, Marcel.

Gehring, C.K., Gigliotti, J.C., Moritz, J.S., Tou, J.C., and Jaczynski, J. 2011. Functional and nutritional characteristics of protein and Lipids Recovered by Isoelectric Processing of Fish by-product and lowvalue fish: A review. Food Chemistry. 124(2): 422431.

Giyatmi, 2001. Prospek Hidrolisat Protein ikan sebagai Pemerkaya Nutrisi Makanan. Makalah. Program Pasca Sarjana. Institute Pertanian, Bogor.

Hartomo, A.J. dan Widiatmoko, M.C. 1993. Emulsi dan Pangan Instan Berlesitin. Andi offset, Yogyakarta.

Ilyas, S. 1993. Teknologi Refrigerasi Hasil Perikanan: Teknik Pembekuan Ikan. Departemen Pertanian, Jakarta.

Mahendran, T., Williams, P.A., Phillips, G.O., and Al-Assaf, S. 2008. New insights into the structural characteristics of Gum Arabic. Journal of Agricultural and Food Chemistry. 56: 9296-9297.

Martinez, K.D., Sanchez, C.C., Ruiz-Henestrosa, V.P., Patino, J.M.R., and Pilosof, A.M.R. 2007. Soy proteinpolysaccharides interactions at the air-water interface. Journal Food Hydrocolloids. 21: 804-812.

Milne, A.C., Avenell, A., and Potter, J. 2006. Meta-analysis: Protein and energy supplementation in older people. Ann. Intern. Med. 144: 37-48.

Nilsang, S., Lertsiri, S., Suphantharika, M., and Assavanig, A., 2005. Optimization of enzymatic hydrolysis of fish soluble concentrate by commercial proteases. Journal of Food Engineering. 70: 571578.

Nugroho, E.S., Tamaroh, S., and Setyowati, A. 2006. Pengaruh konsentrasi Gum Arab dan dekstrin terhadap sifat fisik dan tingkat kesukaan temulawak (Curcuma Xanthorhiza Roxb) madu instan. LOGIKA. 3(2).

Ovissipour, M., Kenari, A.A., Motamedzadegan, A., Rasco, B., Safari, R., and Shahiri, H., 2009. The effect of enzymatic hydrolysis time and temperature onthe properties of protein hydrolysates from Persian sturgeon (Acipenser persicus) viscera. Food Chemistry. 115: 238-242.

Putro, S. 1986. Studies on shrimp waste fermentation for feed II. Effect of invironmental conditions on the shitinoclastic activity of selected chitinoclasts. Jurnal Penelitian Pasca Panen Perikanan. (50): 1-8.

Park, Y., Zhao, T., Miller, N.G., Kim, S.B., Accardi, C.J., Ziegler, T.R., Hu, X., and Jones, D.P. 2012. Sulfur amino acid-free diet results in increased glutamate in human midbrain: a pilot magnetic resonance spectroscopic study. Nutrition Journal. 28: 235-241.

Ruttanapornvareesaku, Y., Ikeda, M., Hara, K., Osatomi, K., Osako, K., Kongpun, O., and Nozaki, Y. 2006. Concentration-dependent suppressive effect of shrimp headprotein hydrolysate on dehydrationinduced denaturation of lizardfish myofibrils. Bioresource Technology. 97: 762-769.

Saleh, M., Ahyar, A., Murdinah., dan Haq, N. 1996. Ekstrak kepala udang menjadi flavor udang cair. Jurnal Penelitian Perikanan Indonesia. 2: 60-68.

Sarkar, S., Gupta, S., Variyar, P.S., Sharma, A., and Singhal, R., 2012. Irradiation depolymerized guar gum as partial replacement of gum Arabic formicroencapsulation of mint oil. Carbohydrate Polymers. 90: 1685-1694.

Silvia, D., Masturah, M.F., Aris, Y.T., Nadiah, W., and Bhat, R. 2012. The effect of different extraction temperatures of the screw press on proximate composition, amino acid content and mineral contents of nigella sativa meal. American Journal of Food Technology. 7(4): 180-191.

Sudarmadji, S., Haryono, B., dan Suhardi. 1997. Prosedur Analisa untuk Bahan Makanan dan Pertanian. Penerbit Liberty, Yogyakarta.

Virag, D., Kiss, A., Forgo, P., Csutoras., and Molnar, S. 2013. Study on Maillard-reaction driven transformations and increase of antioxidant activity in lysine fortified biscuits. Microchemical Journal. 107: 172-177.

Wenhong, C., Chaohua, Z., Pengzhi, H., Hongwu, J., Jiming, H., and Jing, Z. 2009. Autolysis of shrimp head by gradual temperature and nutritional quality of the resulting hydrolysate. Food Science and Technology. 42: 244-249.

Xu, J., Zhao, W., Ning, Y., Jin, B., Xu, B., and Xu,X. 2012. Comparative study of spring dextrin impact on amylose retrogradation Journal of Agricultural and Food Chemistry. 60: 4970-4976.

Yebeyen, D., Lemenih, M., and Feleke, S. 2009. Characteristics and quality of gum arabic from naturally grown Acacia senegal (Linne) Willd. trees in the Central Rift Valley of Ethiopia. Food Hydrocolloids. 23: 175-180. 